\title{
Self-Regulated Learning of Mathematics for Teacher Prospectives in the Development of Student E-Worksheets
}

\author{
Kusno1, Eka Setyaningsih ${ }^{2}$ \\ 1,2Mathematics Education Department, Universitas Muhammadiyah Purwokerto, Indonesia \\ kusnoump@gmail.com¹, ekasetyaning13@gmail.com²
}

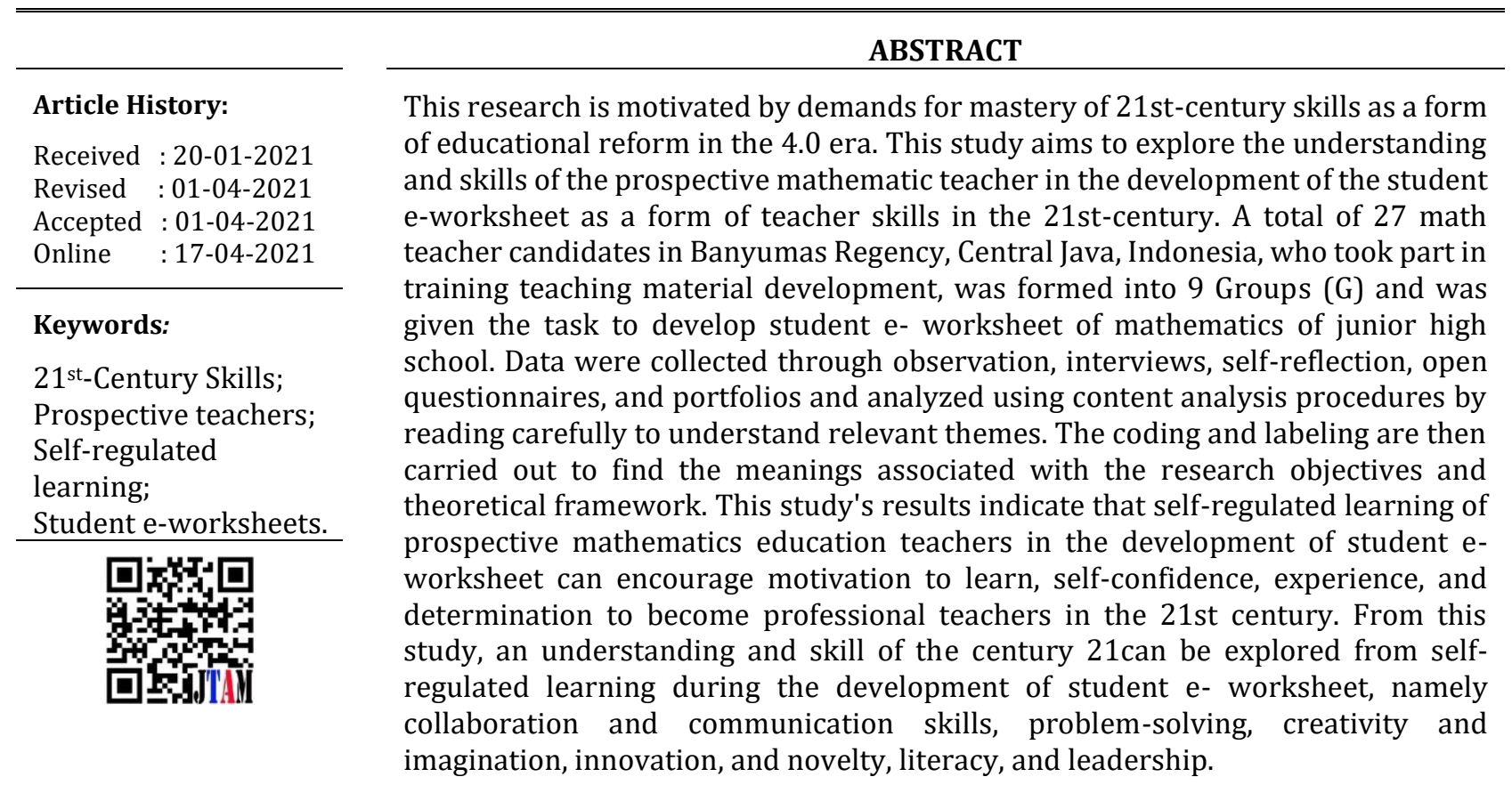

doi) crossref

https://doi.org/10.31764/itam.v5i1.3911

This is an open access article under the CC-BY-SA license

\section{A. INTRODUCTION}

The 21st-century is marked by the 4.0 era, demanding the world of education to reform the implementation of education as a whole (Malik, 2018). Teachers are required to facilitate the learning of their students by utilizing digital technology to obtain the required knowledge quickly (Tomte, 2013). Teachers in the future must be willing and able to prepare teaching materials easily accessible by students(Deed et al., 2014). For this reason, teacher candidates must be trained in 21st-century skills as a basis for developing learning in the modern era. Ghafar (Ghafar, 2020) argues that 21st-century skills needed to face the challenges of the workforce are: (a) critical thinking skills, collaboration and leadership, (b) agility and adaptability, (c) initiative and entrepreneurial spirit, (d) able communicate effectively both verbally and in writing, (e) able to access and analyze information, and (f) have imagination and curiosity. Meanwhile, according to Redhana (Redhana, 2019), 21st-century skills include: (a) critical thinking skills, (b) communication and collaboration skills, (c) ability to create and renew, (d) literacy capabilities in information and communication technology, (e) ability to develop creativity and innovation, (f) the ability of problem-solving and contextual learning. 
The higher education curriculum is designed to facilitate students in presenting the material and learning experience needed by the workforce (Sung et al., 2016). Higher education must pay great attention to the transformation of learning that can facilitate learning creativity following their settings (Mccarthy, 2013). Prospective teachers must be able to utilize the knowledge gained to study, discuss, and solve real problems experienced in life, especially in the development of teaching materials (Kinay \& Bagceci, 2016). The education reform process is expected to encourage new ideas in thinking and produce useful learning concepts. Selfregulated learning is a form of student creativity to organize learning independently (CHENG, 2011).

Moreover, self-regulated learning is also intended to equip students with the skills they need now and in the future (Ayu Lestari \& Widada, 2017). Self-regulated learning can be a strategic choice in achieving learning objectives because it can bring up various ways of organizing learning (Al-rawahi, 2015). Self-regulated learning also allows students to construct their understanding of solving real problems and reflect on their learning experiences (Jakešová \& Kalenda, 2015).

According to social theory, adults learn by constructing meaning from their experiences. The lecturer's role only gives students various opportunities to gain knowledge and skills (Guo, 2014). Students must be given many opportunities to develop teaching material projects to collaborate, participate in discussions, and participate in discussions, and various experiences through experiments (Curtis \& Lawson, 2001). Experimental learning is the ideal approach to achieving educational empowerment principles (Wrenn \& Wrenn, 2009) because the results of more concrete direct experiences are easily identified and can be applied. Students can identify changes that have been made through learning experiences that lead to increased active student involvement, motivation, and self-confidence. Argote \& Spektor (Argote \& MironSpektor, 2011) states that learning experience is the creation of knowledge through experience conversion. According to him, concrete experiences and abstract conceptualizations help capture experiences, while reflective observations and active experiments change this experience. Reflective learning enables students to develop critical thinking skills, develop selfawareness towards their learning, and develop their organizing abilities. Experience-based learning gives positive results (Lillyman \& Bennett, 2014) because students actively participate in their learning.

Mahmoodi, Kalantari \& Ghaslani (Mahmoodi et al., 2014) suggested that self-regulation is deliberate planning, monitoring, and regulation of cognitive processes, affective behavior, or motivation towards completing academic tasks. Students engage physically, intellectually, and emotionally in their learning (Koca, 2016) and analyze their learning experiences. Through reflection, students can turn experiences into knowledge, which is beneficial to their lives (Chang, 2019). They develop the ability to integrate the insights they have gained in their life experiences to make better choices to improve the effectiveness of learning through reflection. During developing teaching materials, they write how to organize their performance and write reflections in their portfolios.

Self-regulated learning is a learning process where students actively and constructively monitor and control their motivation and behavior towards completing academic tasks (Tanriseven, 2014). Self-regulated learning drives students to manage resources, set goals, raise expectations of success, and deep cognitive involvement. Students who manage themselves are motivated to complete academic assignments, have expectations of success, use specific learning strategies, have a great sense of responsibility in achieving expectations, and self-reflect. Independent learning regulates several strategic categories that are very important in students' personal development, namely motivation, metacognition, cognition, and behavior. Self-regulated learning can encourage someone to set goals, evaluate, and adapt measurably to encourage learning achievement (Savira \& Suharsono, 2013). Self-regulated learning requires 
students to regulate and monitor their thoughts, feelings, and behavior to achieve goals. In selfregulated learning, students must explore knowledge, monitor and manage emotions, monitor the achievement of goals, and self-evaluate. Self-regulated learning is a process that helps students manage their thoughts, behavior, and emotions to successfully navigate their learning experiences (Buzza \& Allinotte, 2013).

Teaching material development projects for students can foster creativity and self-directed learning, directed themselves through authentic assessment. Independent learning is learning that they set themselves, not determined by the lecturer or facilitator. There are four assumptions about how students can organize themselves in their learning, namely: (1) students can monitor and regulate cognition, behavior, motivation, processes that depend on several factors including individual differences, (2) students are involved in the learning and active construction process establishing their own goals, (3) all student behavior is directed at the goals and self-regulation processes including modifying behavior to achieve goals, (4) automated behavior mediating the relationship between student performance, contextual factors, and individual characteristics. Self-regulated learning and authentic assessment allow individuals to be responsible for planning, implementing, and evaluating. These skills include setting learning objectives, assessing whether learning objectives are being met, and replanning based on their judgment. Students will become independent, able to direct their learning, and subsequently become lifelong learners. In the teaching material development project, students are given full autonomy to plan and take full responsibility for the product's success. Autonomous learning involves applying personal initiatives to encourage individuals to find resources and opportunities for historical learning. Yeng and Husain (Foo \& Hussain, 2010) explained a learning curve associated with independent learning. According to him that coaching in a project-based learning environment can promote directed independent learning.

Johns (Johns, 1997) states that design is a discipline that uses sensitivity and methods to match people's needs with what is technologically feasible with what strategies can be converted into value benefits according to community needs. By considering that prospective mathematics teachers in Banyumas Regency can grow into independent learners, the researcher is confident that they can act as designers, participants, and authentic assessments. Independent learning aims to encourage students to become more involved in making decisions about what and how they learn. Thus they can develop communication and collaboration skills to explore critical and creative thinking. These skills need to be identified, clarified, reflected, and explored as a form of 21st-century skills in developing teaching materials. Students also need to be encouraged to make choices and make their voices heard to coexist and contribute to the learning community. All of this can be taken into account when lecturers as facilitators prioritize pedagogics, focusing on their teaching practice.

Prospective mathematics teachers have a unique way of designing mathematics teaching materials to produce their best work. It is undeniable that currently, millennials are far more. Potential in mastering media literacy than the older generation, but how do they elaborate their ideas with 21st-century skills? Many of them escape attention. For this reason, it is necessary to develop research that can accommodate self-regulated learning in developing e-mathematics teaching materials in junior high schools. This will be more meaningful, where students can act as developers in creating e-teaching materials. The urgency of this research is to encourage higher education to reform its learning technology by exploring innovative ideas and thoughts. This research contributes to the concept of teaching material development and technology integration because it provides insights to academics about how technology can be utilized to engage students in designing a project by increasing their learning through the design and development of real assignments. Self-regulated learning consists of three phases: the thinking and planning phases, the performance monitoring phase, and the reflection phase on performance (Jansen et al., 2019). Students analyze the learning task in the thinking and 
planning phase and set specific goals for completing the task. In the monitoring phase of student performance using strategies designed to achieve progress in learning, monitor the effectiveness of using these strategies as motivation in achieving goals in the reflection phase on student performance evaluating the performance of the learning task concerning the effectiveness of that strategy. At this stage, students must manage their emotions related to the results of the learning experience. Self-reflection is used as a material consideration in planning and objectives in the next cycle.

To improve 21st-century skills, teacher candidates must be trained to have sensitivity in dealing with problems, be able to identify problems, formulate problems, be able to determine problem-solving strategies, solve problems, and be able to solve problems to reflect on actions taken. In determining problem-solving strategies, the prospective teacher must be trained to have creativity and innovation by criticizing past experiences and updating them for the future according to growing needs. In this case, teacher candidates are motivated to find new ideas that are more effective and able to express these ideas in writing in models, symbolic, graphical, pictures, diagrams, and others so scientifically justified. Other than that, It was also facilitated to express ideas verbally so that exchanges of ideas would complement each other. Based on these descriptions, the purpose of this study is to explore mathematic prospective teacher understanding of and skills in developing student e-worksheet as a form of teacher skills in the 21st-century.

\section{B. METHODS}

This research is qualitative research with a grounded theory approach and case studies to explore prospective teachers' understanding and skills in developing information technologybased student electronic worksheets on junior high school mathematics material. Researchers redesign learning by accommodating various thoughts, feelings, principles, beliefs, and actions chosen to develop teaching material (Trigwell, 2012). Researchers collect learning evidence to provide feedback, explore how they do a comprehensive organization in preparing eworksheets involving 21st-century skills. This research allows researchers to study the problem in-depth based on what they think and develop (Sangster-Gormley et al., 2013). This research also reveals the meaning of deeper self-regulation during the design and development of student e-worksheet through narrative descriptions. In this study, as many as 27 candidates for mathematics teachers in Banyumas Regency, Central Java, Indonesia was given the training to develop teaching materials, formed into nine working groups to compile electronic student worksheets on junior high school mathematics material. During the drafting process, researchers documented their experiences through observation, interviews, self-reflection, open questionnaires, and portfolios.

Through observation revealed how their activities in solving problems. Through interviews and self-reflection revealed how self-regulated learning could motivate, foster self-confidence, provide experience, raise student determination as prospective teachers in the 21st-century. Through open questionnaires will be revealed how they start writing student electronic worksheet, how steps are conducted in developing e-worksheets, how to compile e-worksheets that have novelty and uniqueness, what forms of novelty and uniqueness will be displayed, how they integrate worksheets with digital technology and how they manage the obstacles encountered in e-worksheets development. Through the portfolio revealed the quality of student electronic worksheet products.

The project to develop a student e-worksheet goes through five stages: preparation, planning, implementation of development, editing, and dissemination. The preparation phase includes a needs analysis, according to current and future demands. The planning phase includes: choosing topics for student electronic worksheet, identifying objectives, and creating writing guidelines. Planning is done in class with students and lecturers' full participation as a 
companion in brainstorming activities. The implementation phase of the development is started with writing what he had designed. Students choose topics based on their interests. The editing stage includes: reviewing the chapter, checking originality, checking and harmonizing the chapter's consistency, and editing the language. At this stage, the authors review what is written and provide feedback on the developed content.

The steps taken by researchers include: preparing data both raw data, transcription, field data, images, and so on, processing and preparing data for analysis such as interview transcripts, scanning material, sorting and compiling data according to information sources, reading all data to capture general ideas contained in participant information, analyze in more detail by coding data. Coding is processing material or information into writing segments before interpreting them, applying the coding process to describe the settings, categories, and themes to be analyzed. Then make a more complex analysis: (1) the researcher reads the full description; (2) the researcher extracts significant statements from each description; (3) statements are summarized into meanings which are further grouped into themes; and (4) researchers integrate themes into narrative descriptions.

\section{RESULT AND DISCUSSION}

From the observation results on the group's performance in the framework of designing and developing student electronic worksheets, they are working compactly, sharing tasks and responsibilities. In carrying out their duties, they organize the team's work so that the student electronic worksheet development process can run well. They do the organizing of teamwork by making work plans and doing work. The implementation found two models of organizing teamwork, namely by planning together and working together and planning together and working according to their duties. This shows that self-regulated learning through student electronic worksheet development projects set up as a group can encourage cooperative or collaborative that synergize with each other to realize the achievement of objectives. Following what is stated by Jdaitawi (Jdaitawi, 2019), self-regulated learning can encourage students to do social connectedness.

Through interviews, it can be revealed the role of student electronic worksheet development projects to increase learning motivation, confidence, experience, and determination to become professional teachers in the 21st-century. Of the nine groups, all of them stated that selfregulated learning through student electronic worksheet development projects could motivate learning them for various reasons. The reasons are interested in revolution 4.0 (G1), adding insight (G2), responsibility training as a teacher in the 21st-century (G3, G7, G8, G9), encouraging to read a lot (G4), is applicable $(G 5, G 6)$. This finding corroborates Cheng's opinion [9], which states that self-regulated learning can control metacognition, motivation, and activeness activities. Self-regulated learning through student electronic worksheet development projects can also increase their self-confidence, with the reason for better meeting the demands of learning needs in the 21st century (G1), more creative and innovative (G2), more daring to express their thoughts (G3), more optimistic (G4), better prepared (G5, G7, G8, G9), and more compact (G6). These findings reinforce what has been stated by Toharudin, Rahmat \& Kurniawan (Toharudin et al., 2019) that self-regulated learning can increase one's confidence in carrying out actions or works. Through student e- worksheet development projects, self-regulated learning can also provide their experience and determination to become professional teachers in the 21st-century.

From open questionnaires and field, notes can be identified some 21st-century skills revealed in self-regulated learning through the development of student electronic worksheets, namely: collaboration and communication, problem-solving, creativity and imagination, innovation and novelty, literacy and leadership. 


\section{Collaboration and Communication}

Self-regulated learning of teacher candidates in the development of student e-worksheet can trigger collaboration and communication skills. They collaborate and communicate with each other, either through direct discussions (face to face) or online. Through the division of tasks and responsibilities, they work together to help one another. Each member interacts to contribute their thoughts, be open, and respect each other. At the time of the discussion designing the student e-worksheet, ideas emerged to gather participants' information. To develop a good student electronic worksheet, planning is needed in needs analysis, concept analysis, and skills analysis (G4). In analyzing needs, it is necessary to determine in advance the type of worksheet to be selected (G1), the psychological condition of the target students (G9), syllabus suitability, and teaching program plan (G5, G6), and the need for relevant reference sources (G2). The idea shows that in self-regulated learning to develop e-worksheets, participants are encouraged to explore ideas to plan an excellent e-worksheets thorough needs analysis to determine the type of worksheets that are usually done at the stage of preparation. At the planning stage, concept analysis, skills analysis, psychological analysis (setting) can be extracted from various relevant reference sources or the results of reflection during learning. What needs to be added from the results of the participant discussion above is an analysis of objectives that can direct operationally how concepts, principles, and skills can be outlined in student e-worksheets according to student life.

\section{Problem Solving}

Self-regulated learning of prospective teachers in student e-worksheet development projects can trigger problem-solving abilities, namely understanding problems, planning solutions, implementing completion plans, and re-examining the process and results of solving. This is in line with Polya's problem-solving theory (Polya, 1973). The action of prospective mathematics teachers in understanding the student electronic worksheet design problem is conducting curriculum analysis, content analysis, and assessment analysis (G1, G2, G3), literacy analysis (G7), context analysis (G6), and comparative analysis (G8). In conducting content analysis and curriculum, they determine the material's scope, which includes the breadth and depth that will be outlined in student electronic worksheets. In analyzing objectives, targets are expected to be achieved through the development of student e-worksheets. In literacy analysis, identifying market share needs is made through the use of digital technology with the necessary features. In the context analysis, needed identification of the social, cultural, and religious values will be integrated into the student electronic worksheet. In a comparative analysis, the comparison is made with another student e-worksheet to do kaizen by taking the advantages and leaving the deficiencies. The compilation of the analysis results raises the idea of the importance of developing electronic worksheets based on cultural contexts and religious values by emphasizing the ability to think at a higher level connected with links to relevant teaching materials as development material. This is what is commonly referred to as the initial and final analysis in developing teaching materials. This shows that self-regulated learning can encourage teacher candidates to be sensitive and understand the real problems that integrate material, educational, and technological elements. In other words, self-regulated learning can encourage learning that emphasizes TPACK (Technological, Pedagogical, Content Knowledge), which is a framework in designing new learning by combining three main aspects (technology, pedagogy, and knowledge content)

After conducting the analysis, the next steps are the formulation of the format, layout, and procedures (G2, G7), the determination of material based on the curriculum (G1), the formulation of a platform of attractiveness and creativity (G1, G3, G4), the determination of features, culture and values in the politeness of the context of the problem according to the needs of students (G8), formulation of objectives (G3, G5). From this, it can be seen that the 
strategy undertaken by prospective teachers as developers is composing the grid of student eworksheet as a reference material to express their ideas in developing student e-worksheets. According to Polya, this stage is called a problem-solving strategy. To design a good student electronic worksheet, it is necessary to design a more operational strategic picture. This stage is often referred to as the initial design or model in design.

The next stage is a discussion to pour and compile ideas and opinions about content or material, choose words or sentences, choose and map pictures and colors, arrange sequences, choose fonts and types of letters, arrange narratives in selected contexts, integrate technology with selected features, searching and selecting related teaching material links. To support this stage, teacher books, student books, GeoGebra, and other relevant sources are used. This activity produced a description of the draft teaching materials in the form of e-worksheets for students. According to Polya, this stage is the implementation of problem-solving following the stages of product development implementation. Fig.1. shows the development of student electronic worksheets (Se-W) design, based on problem-solving

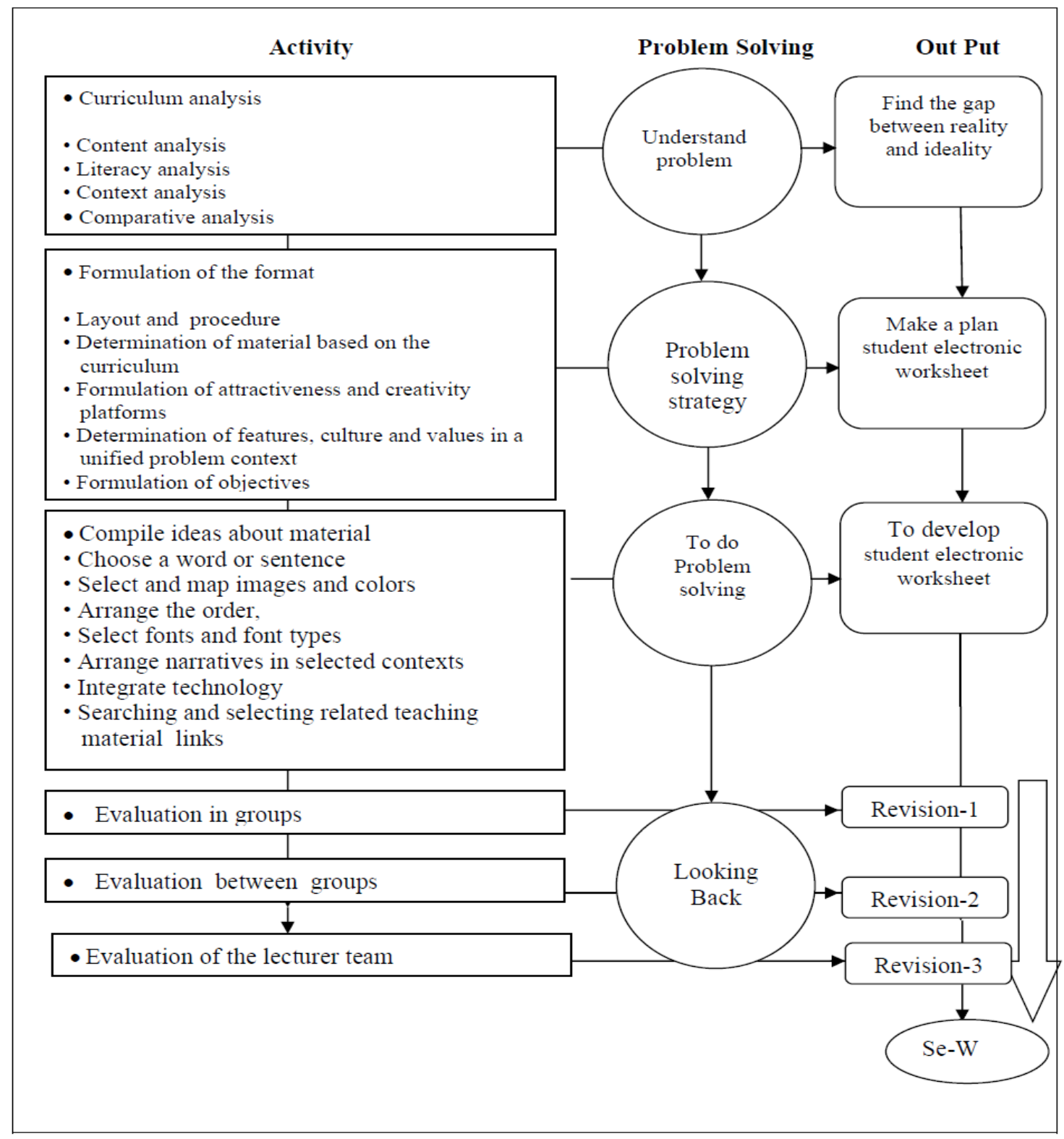

Figure 1. Development of student electronic worksheets (Se-W) design, based on problem-solving 


\section{Creativity and Imagination}

Self-regulated learning process mathematics prospective teachers in developing student electronic worksheets can trigger creativity and imagination. Creativity is revealed in the form of new ideas that emerge in response to social changes and demands. The emergence of creativity is caused by several things as follows (1) the demands of students' needs in the 21st century and their relevance to the 4.0 era, (2) reading and comparing student electronic worksheets that already exist in various online media, (3) practical experience in the field. Furthermore, these three things settle in their minds and bring up new imaginations expressed in ideas and actions. The demand for strengthening character education has triggered the idea of integrating spiritual and social values in teaching materials. For example, from portfolios, it was revealed that some linked mathematics with the context of religiosity; for example, worship activities, social interaction, and brotherhood were also related to social activities such as paying zakat, calculation of inheritance, and other social activities.

\section{Innovation and Novelty}

The self-regulated learning process of prospective teachers in developing student electronic worksheets can trigger innovation and novel ability. The ability of innovation for example, on electronic worksheets, students developed contextual issues that demand higher-order thinking skills (HOTS), there is integration between values, attitudes, knowledge, and skills in a unified life context and the emergence of several features that make it easier for students to study more material in-depth through the links provided. This is what is considered a novelty in the development of teaching materials. As for innovations in digital technology integration, especially the use of applications, it has not been so apparent in the development of electronic student worksheets. For example, how to use the game or the rules of the game in the work of electronic student worksheets to simply use the cell phone as a medium. For this, it may have to involve elements of experts in the field of software.

\section{Literacy}

Process of self-regulated learning of prospective mathematics teachers in the development of electronic worksheets students can trigger prospective teachers' literacy skills both in terms of reading and using media. During the process of developing student electronic worksheet, at least they read Task Books, Student Books, Syllabus, Modules, Papers, Guides to the steps of developing teaching materials, Journals, Blogs, Teacher E-Books, and Student E-Books, student electronic worksheet, as well as other examples of E-Teaching Materials sourced from the internet. While media literacy can be seen from how they use digital media during the development of student electronic worksheets. Media literacy, among others, can be seen from activities (1) access to references and other information through digital technology, (2) designing and developing teaching materials such as designing graphics using Geogebra applications, editing, (3) disseminating work through uploading or sharing through Edmodo to lead students to answer or upload answers.

\section{Leadership}

The process of self-regulated learning of prospective mathematics teachers in developing student electronic worksheets can trigger leadership management skills in the face of difficulties. There are some difficulties and solutions taken by the prospective teacher during student electronic worksheets, such as the difficulty of time, facilities, skills, and diversity of opinions. Because the lecture schedule is dense, there are various assignments, with busy schedules, the curfew in the hostel is limited, so they make more use of the time between lectures. The quality of the laptop is not right, so it has to look for a laptop. That can meet the needs of teaching material development standards. Lack of mastery of IT writers, so they must 
learn to maximize IT use, especially in designing teaching materials. The difficulty of uniting different thoughts from one another, because the ideas conveyed by each member have a good idea, so they must do the elaboration carefully and precisely, the difficulty in determining the material following the conditions of students, many different ideas so they must conduct a review varied sources of information.

\section{CONCLUSION AND SUGGESTIONS}

Self-regulated learning of prospective teachers in the development of student electronic worksheets is one way that has been proven to facilitate the development of abilities needed in the 21st century or 4.0 era. Self-regulated learning of prospective mathematics teachers in developing student electronic worksheets for junior high school mathematics can encourage student motivation, confidence, experience, and determination to become professional teachers in the 21st century. Self-regulated learning of mathematics teacher candidates in the development of student electronic worksheets turned out to be able to encourage them to explore ideas, implement development designs through problem-solving, collaborate and communicate, do creativity and imagination, find innovation and novelty, do multi-modal literacy, and conduct leadership management in dealing with problems. Thus self-regulative learning in the development of e-teaching materials is an essential alternative in preparing teacher skills in the 21st century.

\section{ACKNOWLEDGEMENT}

The researcher would like to thank UMP, who provided research funding assistance, and all participants who provided in-depth information for this research's needs.

\section{REFERENCES}

Al-rawahi, N. (2015). Self-Regulated learning processes utilized by Omani Physical Education candidates in mastering sport skills. Journal of Physical Education and Sport Management, 6(4), 25-31. https://doi.org/10.5897/JPESM2015.0225

Argote, L., \& Miron-Spektor, E. (2011). Organizational learning: From experience to knowledge. Organization Science, 22(5), 1123-1137. https://doi.org/10.1287/orsc.1100.0621

Ayu Lestari, N., \& Widada, W. (2017). Pengaruh strategi pembelajaran self regulated learning in mathematics berbasis pemecahan masalah terhadap kemampuan metakognitif siswa di SMA negeri 2 Bengkulu. Jurnal Pendidikan Matematika Raflesia, 2(2).

Buzza, D., \& Allinotte, T. (2013). Pre-service Teachers' Self-Regulated Learning and their Developing Concepts of SRL. Brock Education Journal, 23(1), 58-76. https://doi.org/10.26522/brocked.v23i1.353

Chang, B. (2019). Reflection in learning. Online Learning Journal, 23(1), 95-110. https://doi.org/10.24059/olj.v23i1.1447

CHENG, C. (2011). The role of self-regulated learning in enhancing learning performance. May.

Curtis, D. D., \& Lawson, M. J. (2001). Exploring collaborative online learning. Journal of Asynchronous Learning Network, 5(1). https://doi.org/10.24059/olj.v5i1.1885

Deed, C., Cox, P., Dorman, J., Edwards, D., Farrelly, C., Keeffe, M., Lovejoy, V., Mow, L., Sellings, P., Prain, V., Waldrip, B., \& Yager, Z. (2014). Personalised learning in the open classroom: The mutuality of teacher and student agency. International Journal of Pedagogies and Learning, 9(1), 66-75. https://doi.org/10.1080/18334105.2014.11082020

Foo, S. Y., \& Hussain, R. M. R. (2010). Self-directed learning in a socioconstructivist learning environment. Procedia - Social and Behavioral Sciences, 9, 1913-1917. https://doi.org/10.1016/j.sbspro.2010.12.423

Ghafar, A. (2020). Convergence between 21st century skills and entrepreneurship education in higher education institutes. International Journal of Higher Education, 9(1), 218-229. 
https://doi.org/10.5430/ijhe.v9n1p218

Guo, L. (2014). Preparing Teachers to Educate for 21st Century Global Citizenship: Envisioning and Enacting. Journal of Global Citizenship \& Equity Education, 4(1), 1-23.

Jakešová, J., \& Kalenda, J. (2015). Self-regulated Learning: Critical-realistic Conceptualization. Procedia - Social and Behavioral Sciences, 171, 178-189. https://doi.org/10.1016/j.sbspro.2015.01.105

Jansen, R. S., van Leeuwen, A., Janssen, J., Jak, S., \& Kester, L. (2019). Self-regulated learning partially mediates the effect of self-regulated learning interventions on achievement in higher education: A meta-analysis. Educational Research Review, 28(June), 100292. https://doi.org/10.1016/j.edurev.2019.100292

Jdaitawi, M. (2019). ERIC - EJ1220207 - The Effect of Flipped Classroom Strategy on Students Learning Outcomes, International Journal of Instruction, 2019-Jul. 12(3), 665-680. https://eric.ed.gov/?id=EJ1220207\#?accno=EJ1220207

Johns, M. (1997). Change by design. Journal of AHIMA / American Health Information Management Association, 68(6).

Kinay, I., \& Bagceci, B. (2016). The Investigation of the Effects of Authentic Assessment Approach on Prospective Teachers' Problem-Solving Skills. International Education Studies, 9(8), 51. https://doi.org/10.5539/ies.v9n8p51

Koca, F. (2016). Motivation to Learn and Teacher-Student Relationship. Journal of International Education and Leadership, 6(2).

Lillyman, S., \& Bennett, C. (2014). Providing a positive learning experience for international students studying at UK universities: A literature review. Journal of Research in International Education, 13(1), 63-75. https://doi.org/10.1177/1475240914529859

Mahmoodi, M. H., Kalantari, B., \& Ghaslani, R. (2014). Self-Regulated Learning (SRL), Motivation and Language Achievement of Iranian EFL Learners. Procedia - Social and Behavioral Sciences, 98, 1062-1068. https://doi.org/10.1016/j.sbspro.2014.03.517

Malik, R. S. (2018). Educational Challenges in 21St Century and Sustainable Development. Journal of Sustainable Development Education and Research, 2(1), 9. https://doi.org/10.17509/jsder.v2i1.12266

Mccarthy, G. (2013). Authentic assessment - key to learning. 81-92.

Polya, G. (1973). Reviewed Work: How to Solve It A New Aspect of Mathematical Method. The Mathematical Gazette, 30, 181. https://doi.org/10.2307/3609122

Redhana, I. W. (2019). Mengembangkan Keterampilan Abad Ke-21 Dalam Pembelajaran Kimia. Jurnal Inovasi Pendidikan Kimia, 13(1).

Sangster-Gormley, E., Martin-Misener, R., \& Burge, F. (2013). A case study of nurse practitioner role implementation in primary care: What happens when new roles are introduced? $B M C$ Nursing, 12(1), 1. https://doi.org/10.1186/1472-6955-12-1

Savira, F., \& Suharsono, Y. (2013). Self-Regulated Learning (Srl) Dengan Prokrastnasi Akademik Pada Siswa Akselerasi. Jurnal Ilmiah Psikologi Terapan, 01(01), 66-75. https://doi.org/10.1017/CB09781107415324.004

Sung, Y. T., Chang, K. E., \& Liu, T. C. (2016). The effects of integrating mobile devices with teaching and learning on students' learning performance: A meta-analysis and research $\begin{array}{llll}\text { synthesis. Computers and } \quad \text { Education, 252-275. } & \text { 94, }\end{array}$ https://doi.org/10.1016/j.compedu.2015.11.008

Tanriseven, I. (2014). A tool that can be effective in the self-regulated learning of pre-service teachers: The mind map. Australian Journal of Teacher Education, 39(1). https://doi.org/10.14221/ajte.2014v39n1.1

Toharudin, U., Rahmat, A., \& Kurniawan, I. S. (2019). The important of self-efficacy and selfregulation in learning: How should a student be? Journal of Physics: Conference Series, 1157(2). https://doi.org/10.1088/1742-6596/1157/2/022074 
Tomte, C. (2013). Digital Competence in Teacher education. Learning \& Teaching with Media \& Technology - ATEE-SIREM Winter Conference Proceedings, March, 173-182.

Trigwell, K. (2012). Scholarship of teaching and learning. University Teaching in Focus: A Learning-Centred Approach, June 2017, 253-267. https://doi.org/10.4324/9780203079690

Wrenn, J., \& Wrenn, B. (2009). Enhancing Learning by Integrating Theory and Practice. International Journal of Teaching and Learning in Higher Education, 21(2), 258-265. http://www.isetl.org/ijtlhe/ 